\title{
Å plastre med penger
}

Penger kan ikke reparere en skade selv om erstatningsrettens oppgave er å reparere. Men penger hjelper når skaden ruinerer økonomien til pasienten og hans familie.

Gjennom flere tiår har mitt hovedfelt som advokat vært personskadesaker av alle slag, men med særlig interesse for pasientskader. Som ung advokat i Troms $\varnothing$ i slutten av 1970-årene fattet jeg interesse for at pasienter som led skade under behandling, hadde et svakt erstatningsvern. Pasientens ærefrykt og ydmykhet for doktoren den gang var nok større enn i dag og få søkte advokathjelp. Men det var ikke lett å godta at han som gikk på egne bein inn på sykehuset, ble trillet ut i rullestol ved utskrivning - helt uten at noen anså seg ansvarlig for den alvorlige pasientskaden. En forventning om å bli hjulpet endte med det motsatte.

Selv så jeg nok ofte legen som selve «fienden»-feilfri som han gjerne fremsto godt støttet av sine sakkyndige kolleger når spørsmål om legefeil ble reist. Legene i sin hvite frakk og jeg min sorte kappe. Legens kliniske skjønn var hevet over jusen, noe domstolene stort sett godtok. Men å stå på og forsøke å avdekke uaktsomhet hos legen som årsak til pasientens skade var en nødvendighet for ansvar. Og på pressebenken satt lokalavisen hvis sympati for pasienten nok ofte var gitt. En pågående advokat ble rimeligvis ikke populær i legekretser.

Heldigvis forsto omsider også myndighetene at pasientenes vern måtte bli bedre, og i 1988 fikk vi Norsk Pasientskadeerstatning (NPE). Heretter skulle krav om skyld hos legen ikke lenger være nødvendig for rett til erstatning. I 2001 ble erstatningsordningen omsider lovfestet. Stortinget som lovgiver presiserte - bl.a. med bakgrunn i en viktig anmodning fra Legeforeningen - at fokus for rett til erstatning nå skulle være skaderesultatet og ikke så mye hva som hadde ført til skaden.

Har så lovgivers intensjoner slått til og hvor er legens plass i dag? Og hva er advokatens rolle i en statlig erstatningsordning? Dette er omfattende spørsmål som jeg bare i kortform kan gå inn på her.

NPE-ordningen var et stort fremskritt, men det store flertall som melder sin skade får fortsatt avslag. Av dem som klager til nemnda, får ca. $10 \%$ medhold. Helt avgjørende for sakens utfall - den gang som nå - er hvordan den sakkyndige lege som forvaltningen benytter, vurderer sakens medisinske aspekter. Fortsatt flyter i stor grad medisin og jus sammen, og det er de sakkyndige leger som i praksis avgjør saken. Det er derfor vesentlig at de sakkyndige er uhildede, med stor faglig integritet og uten $ø$ konomiske eller andre bindinger til partene. Enda viktigere blir dette når pasienten velger å gå rettens vei etter et avslag også i nemnda. Advokatens oppgave er på alle disse trinn å påvirke valget av best mulig sakkyndighet.

Det er ikke enkelt for en sakkyndig lege å skjelne mellom det som før het culpa og hva det i mandatet i dag spørres etter. nemlig om behandlingen har vært i henhold til alminnelig medisinsk praksis og retningslinjer eller - for den saks skyld å skille mellom hva av skaden som tilhører grunnsykdommen og hva som er en behandlingsskade.

Men i tillegg til rollen som sakkyndig kommer selvsagt fortsatt alle legers utfordring når behandlingen går galt og skade oppstår. Hvor åpen kan legen da være overfor pasienten, og hvordan hjelpe pasienten videre?

Pasientens lege og pasientens advokat tjener samme formål. Der legen avslutter sin rolle, tar pasientadvokaten over. Kanskje kan en erstatning bøte på såret.

At leger tradisjonelt har sett med skepsis på erstatningsadvokaten er lett å forstå, ikke minst på grunn av den personlige belastning en rettssak og dens offentlighet lett førte med seg. Men før Norsk pasientskadeerstatning var heller ikke legen pasientens motpart. Motparten er nå staten. Legen selv er sjelden inne som noe viktig vitne. Legens risiko er fortsatt begrenset til de tilfeller hvor legen en sjelden gang skulle skade en pasient som følge av grov uaktsomhet og bli avkrevd såkalt oppreisningserstatning. Og slike saker løses gjerne i stillhet om man er ydmyk nok.

I Norge har vi en høyt kvalifisert og samvittighetsfull legestand. Noen sjeldne feiltrinn vil aldri endre dette inntrykk. Jeg sier dette også ut fra egne skjellsettende erfaringer som pasient. Den gullstandard jeg som pasient ble til del tenker jeg ofte på.

Til slutt: Det er verken farlig eller skamfullt å erkjenne at noe gikk galt. Pasienten er i stor grad åpen for å forstå og tilgi. Det er dette som også skaper den tillit og trygghet som vi alle ønsker.

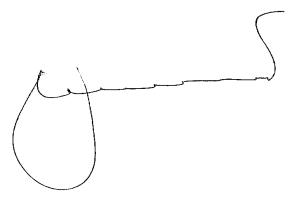

